\title{
THE IMPACT OF ADVANCED CANCER ON THE FUNCTIONAL STATUS OF PATIENTS ATTENDING ONCOLOGY CLINICS IN SELECTED URBAN AREAS
}

\author{
Hilla-llse Luise Brink
}

\begin{abstract}
The primary purpose of the study was to obtain information from out patients with advanced cancer on their

functional status, and to construct a profile of existing needs, which may be of use for nurses involved with planning and rendering support. A secondary purpose was to determine whether an existing instrument would provide a reliable means of assessing the degree of symptom distress and its impact on the functional status of patients with advanced cancer in this country.

The population consisted of patients who had been diagnosed as suffering from cancer with metastases to at least one of the following organs - liver. lung, bone or brain - and who were under active therapy or supervision at an oncology clinic of a large hospital as out patients. Six clinics were selected: however, only four participated. Random samples of one or two patients per clinic day were selected during the period from October 1987 10 January 1988 for interviews. A total of 146 patients participated. The Chairmen of the Regional Oncology Nursing

Societies were the chief investigators.

Selected oncology nurses assisted with
\end{abstract}

\section{data collection.}

The instrument was found to be reliable and a positive relationship between symptom distress and functional status was established. Areas of problems and concerns of cancer patients were identified and a profile was constructed as an aid to nurses planning or rendering cancer care.

\section{Uittreksel}

Die primêre doel van die studie was om inligting te verkry met betrekking tot die funksionele status van buitepasiënte met gevorderde kanker en om $n$ profiel van bestaande behoeftes daar te stel. Laasgenoemde kan moontlik van nut wees vir verpleegkundiges gemoeid met die beplanning van dienste vir sodanige pasiënte of met betrekking tot die onderskraging van hierdie groep pasiënte. 'n Sekondêre doel was om die betroubaarheid van ' $n$ bestaande instrument te bepaal, ten opsigte van die meting van die mate van nood voortspruitende uit die simptome van kanker sowel as die impak hiervan op die funksionele status van pasiënte met gevorderde kanker in ons land.
Die populasie het bestaan uit pasiënte met in diagnose van kanker met uitsaaings na ten minste een van die volgende organe naamlik die lewer, longe, been of brein, wat of aktiewe onderhandelinge ondergaan of opgevolg word na behandeling by $n$ onkologiese kliniek van 'n groot hospitaal. Ses klinieke is geselekteer waarvan slegs vier deelgeneem het. 'n Ewekansige steekproef van een of twee pasiënte per kliniekdag is getref gedurende die periode Oktober 1987 tot Januarie 1988 vir onderhoudvoering. Eenhonderd sesen-veertig pasiënte het deelgeneem. Die voorsilters van die streeks-onkologiese genootskappe was die hoofondersoekers. Geselekteerde onkologie verpleegkundiges het ook gehelp met data versameling.

Die instrument is betroubaar bevind en in positiewe verband tussen simptoomnood en funksionele status is bevind.

Probleem-areas en bekommernisse van kanker pasiënte is geidentifiseer en in profiel daargestel om as hulpmiddel te dien vir verpleegkundiges wat met kankersorgbeplanning of onderskraging gemoeid is.
The patient with a diagnosis of advanced cancer is exposed to many difficulties. Not only is his future unpredictable but the methods of treatment used to alleviate his condition are often very toxic and may induce a variety of unpleasant side effects and problems. As the disease progresses it may disrupt his pattern and quality of life. In such a situation support and skilled understanding from the nurse is most crucial for the patient and his relatives and friends.

To plan and render the support and care needed by the noninstitutionalised patient with advanced cancer, the nurse needs to be aware of the impact advanced cancer or its treatment may have on the activities of daily living as well as on the social and emotional well-being of the patient. Care plans need to be directed at specific concerns causing stress to the patient. However, very little guidance on this dimension can be obtained from the contemporary literature. Very few relevant nursing studies have been reported on this. This is probably due to the difficulty inherent in the functional status of patients with advanced cancer, the many variations of cancer and the widely differing circumstances which may influence the quality of life. Those studies that do exist were conducted in America and England.

A pilot study conducted by McCorkle (1976) revealed that self-care social and mobility problems were major concerns of patients with cancer. In a subsequent study McCorkle and Young (1978) developed a scale dealing with the three major problem areas identified by cancer patients in the 1976 pilot study for use in conjunction with a 10 item symptom distress scale. The validity and reliability of this scale were established on sixty patients with progressive chronic illnesses (Benoliel, McCorkle and Young 1980). The scale has since been revised and used with other patient groups, e.g. those suffering from lung cancer and myocardial infarction (McCorkle and Benoliel 1981), and melanoma and quality of life in the elderly (Young 1981).

Holmes and Dickerson (1987) designed and evaluated a self-assessment instrument for detecting the changes resulting from the presence of malignant disease or from its treatment on a sample of 72 patients admitted to the Oncology Unit at St. Lukes Hospital Guilford. The items selected for inclusion in the measurement instrument were based on the symptom 
distress scale and on the concerns of cancer patients identified by McCorkle and Young (1978). The researchers found the instrument developed in this study to be a reliable, reproducible and a valid means of assessing patient well-being and quality of life. It is simple to use, easy to complete and quick to score.

From the completed questionnaires it was possible for the researchers to identify those areas of particular concern to individual patients and it was found that use of the instrument provided a useful mechanism by which patient counselling could be initiated once particular problems had been identified. Further implications for nursing derived from this study were that the patients involved in the study associated their feelings of isolation with an inability to discuss their anxieties with members of the nursing staff. The prime reasons given were "the nurses are too busy to waste time talking to me". The researchers also drew attention to the fact that many of the symptoms associated with malignant disease or with its treatment (e.g. nausea, fatigue or anorexia) are not immediately apparent and that it is quite possible that the nurse or even a close family member would not be aware that the patient was suffering such a symptom unless he pointed this out. In addition, the degree of distress experienced by a particular patient, whatever its cause, cannot be readily assessed and can only be guessed at by an observer. The use of the questionnaire allows the presence or severity of such distress to be identified and an analysis of the individual symptoms, or the relationship between symptoms, provides valuable information, which could enable care to be planned more effectively and improve the evaluation of the prescribed care (Holmes and Dickerson 1987: 23).

In view of the fact that no published research on this dimension of oncological nursing was available in this country and on the basis of the value the studies just described could hold for oncological nursing in this country, it was concluded that a research study in this area was indicated.

\section{PURPOSE OF THE STUDY}

The primary purpose of this study was to obtain information from patients with advanced cancer, who are attending oncology clinics on their well-being, in order to construct a profile of existing needs. It was reasoned that such finding might be useful for nurses involved in planning and rendering support.

The secondary purpose was to determine whether the assessment instrument provided a reliable means of conducting assessments locally with a minimum expenditure of time.

\section{OBJECTIVES}

The objectives of this study were to

- assess the degree of symptom distress and its impact on the functional status of patients with advanced cancer, as reported by them.
- estimate the level of difficulty being experienced by patients with advanced cancer in the personal, social and instrumental activities of daily living.

- establish any other problems which the patient may have.

- test an existing instrument measuring the aspects under study on patients in this country for reliability and validity.

\section{UNDERLYING ASSUMPTIONS}

The development of the study depended upon the following fundamental assumptions.

1. Patient needs are a practical basis for care and programme planning, and implementation and evaluation of service.

2. The patient himself can be the only proper judge of his well-being and should thus be included in assessments of his health status.

3. Nurses involved in the care of these patients should be able to make valid judgements on information obtained from patients and recognise the importance of these for planning future care and evaluating existing care.

\section{DEFINITIONS}

In this study "a patient with advanced cancer", refers to a person who has been diagnosed as suffering from cancer with metastases to at least one of the following organs - liver, lung, bone or brain - and who is under active therapy or supervision at an Oncology Clinic of a hospital he attends as an Outpatient.

Functional status for purposes of this study refers to the level at which a person is functioning in any of a variety of areas, such as physical health, activities of daily living, self maintenance, role activity, social activity and emotional status. Functional status in activities of daily living may range from independence to complete dependence.

\section{METHOD}

For this field study design, six large oncology clinics, one in each of the regions represented on the National Oncology Nursing Society, were originally selected as sites for data collection. Each of the Clinics was part of a large hospital complex. For the purposes of data collection, each of the regions was treated as a separate unit. Within each region the Chairman of the Regional Oncology Nursing Society, who is also a committee member of the National Oncology Nursing Society, acted as chief field investigator for the researcher. Each chief investigator selected and briefed two or three persons with Oncological nursing experience to assist with data collection.

The population for the study consisted of patients with advanced cancer who attended selected Oncology Clinics as outpatients during the period October 1987 to January 1988. The original plan for the sampling procedure was to randomly select and interview one or two patients per clinic session, depending on the attendance rate, until a sample of 50 patients was obtained from each clinic. This would have ensured a total sample of 300. However, because of work pressure and other factors pertaining to the interviewers, this was not always possible. Eventually by the middle of March 1988 data on only 148 patients from four regions, one from each province, had been received. Included in this sample were 2 children aged 13 and 15 years whose data were not usable for purposes of analysis, as the instrument had been designed for adults.

\section{THE INSTRUMENT}

A semi-structured interview schedule consisting of three sections was designed to assist the investigators with data collection and also to provide an opportunity for the patient to share his or her perceptions of what was happening.

The items selected for inclusion in Section 1 of the measurement instrument were based on an existing symptom distress scale (McCorkle and Young 1978), which has already been found to be a reliable means of assessing patient wellbeing, both in the USA and the UK (McCorkle et al. 1986: 2; Holmes and Dickerson 1987: 22)

Items in this section related to both symptoms of the disease and the side effects of treatment. The items for Section 2 were selected to assess the impact of distressing symptoms on the functional status of patients and were based on the scales developed by McCorkle and

Benoliel (1981). Six personal competencies, which are considered to be basic self-care activities of a normal adult, and four social competencies were included. (See Table I) The third section consisted of general background information.

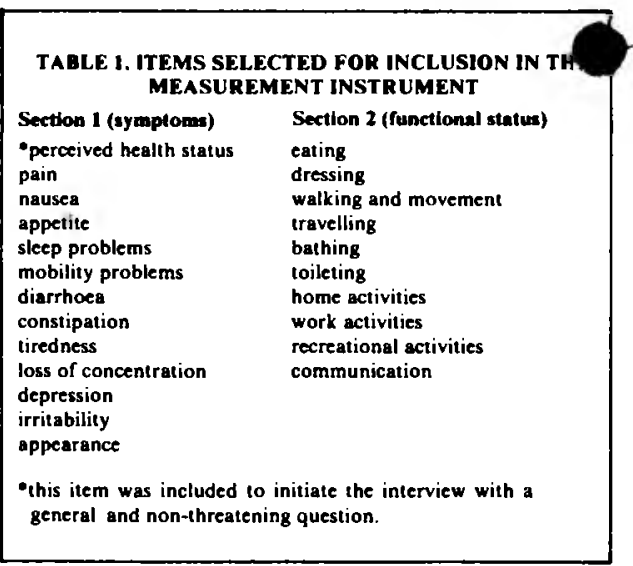

In addition to the semi-structured interview schedule an interview guideline was prepared for each of the investigators to ensure a relatively uniform approach and focus. In this guideline interviewers were requested to first create a conducive climate for interviewing by engaging in normal introductory talk and then to obtain informed consent. Reluctant patients were not to be forced to participate. The actual interview was to be initiated with a general non-threatening 
question such as, for example, by asking the patient how he has been getting on since he last visited the clinic. Is he feeling the same, better, worse or fluctuating? This question was then to be expanded to the problem areas. The questions were constructed on the principle that as many questions as necessary should be asked, so as to be able to determine where a patient would score on a standardised scale. If the patient gave enough information on the first question of an item, no further questions on that item would be necessary. If more information was required, more detailed questions had to be asked. The score dimensions for each scale were also included in the guideline.

Permission for the study was sought from the various authorities responsible for the clinics, and was granted.

\section{ANALYSIS OF RESULTS}

The data from the patients were edited, categorised and coded.

Symptom distress was coded on a 4 point Likert-type scale with 1 indicating minimal distress; 2 - moderate distress; 3 - considerable distress and 4 - high distress. Summed scores could range from 13 to 52 with higher scores reflecting higher symptom distress.

Personal competencies were coded on a 6 - point Likert-type scale with 1 indicating independence and 6 complete dependence.

Home, work and recreational activities were coded on a 4 point Likert-type scale with I indicating (no change - usual activity) and 4 - activities no longer being performed, while the communication competency was coded on a 3 point scale (see Table 2).

The codes were first transferred onto a coding sheet by the researcher and then entered in the computer. The SAS programme package was used for com computations and data analysis.

\section{RELIABILITY AND VALIDITY}

The reliability of the instrument was established by computation of Cronbach's coefficient alpha. $(\alpha)$ Such computation yielded an $\alpha$ of ,84 on Section I symptom distress and 0,90 on Section 2 Activities of daily living. As this provides a conservative estimate of reliability the selection of this instrument is justified Reliability coefficients reported by Holmes and Dickerson (1987) for this instrument on a smaller sample $(n=70)$ was 0,9 for symptom distress and 0,7 for activities of daily living.

Face and content validity was established by including items supported in the literature and in a series of previous studies as having an impact on the life of patients with advanced disease.

\section{RESULTS}

All patients selected for an interview responded positively when asked to participate. The majority responded spontaneously to questions and expressed great interest in the study. Many wanted to know whether the information they provided would benefit other patients. Except for finding time for interviewing during very busy clinics due to staff shortages, the interviewers experienced no difficulties. The average interview time was 20 minutes, the range being 10 to 30 minutes.

\section{SOME CHARACTERISTICS OF THE SAMPLE}

Of the 146 patients on whom usable data was available, fifty-nine $(40,4 \%)$ were male and eighty-seven $(59,6 \%)$ female, ranging in age from 20 to 81 years. Twenty-five $(17,1 \%)$ were Black, fourteen $(9,6 \%)$ Coloured and one-hundred-and-seven $(73,3 \%)$ white.

One-hundred-and-six $(72,6 \%)$ were married, ten $(6,8 \%)$ single, twenty-one $(14,4 \%)$ widowed and nine $(6,2 \%)$ separated.

The patients had a variety of life-styles, the majority $(60,3 \%)$ lived in a marital relationship with a spouse or with a spouse and children. Forty-two $(28,5 \%)$ lived with relatives or friends, ten $(6,8 \%)$ lived alone and $\operatorname{six}(4,1 \%)$ lived in an institutional setting such as an old age home, a nursing home or a religious community. The majority $(69,9 \%)$ lived in their own home, the remaining forty-four $(30,1 \%)$ lived in rented flats or rooms or in institutions. Fifty-seven (39\%) still had dependants and eighty-nine $(61 \%)$ had none.

\begin{tabular}{|c|c|c|}
\hline Activities & innerviem euiate & Coding of items \\
\hline \multicolumn{3}{|l|}{ Activities of daily living } \\
\hline $\begin{array}{l}\text { Eating } \\
\text { Dressing } \\
\text { Walking and movement } \\
\text { Travelling } \\
\text { Bathing } \\
\text { Toileting }\end{array}$ & $\begin{array}{l}\text { Do you have any problems with regard to } \\
\text { That you did not have before your illness? } \\
\text { Does it take you more time? } \\
\text { Do you need help? }\end{array}$ & $\begin{array}{l}\text { 1. No help required } \\
\text { 2. Activity involves minor changes } \\
\text { 3. Requires heip of equipmen! } \\
\text { 4. Help of another person } \\
\text { 5. Much help } \\
\text { 6. Completely dependent }\end{array}$ \\
\hline \multicolumn{3}{|l|}{ Instrumental activitiea } \\
\hline $\begin{array}{l}\text { Work } \\
\text { Home }\end{array}$ & $\begin{array}{l}\text { Can you describe what your primary } \\
\text { responsibilities have been }\end{array}$ & $\begin{array}{l}\text { 1. Unchanged } \\
\text { 2. Some change } \\
\text { 3. Restricted activity } \\
\text { 4. No activity }\end{array}$ \\
\hline
\end{tabular}

Social aetivities

In what ways have these changed

Responds normally

2. Adds much irrelevant information

3. Requires prompting

Forty-eight $(32,9 \%)$ of patients had given up their job because of illness. Thirty-three $(22,6 \%)$ had retired, twentyfive $(17,1 \%)$ were working full-time, six $(4,1 \%)$ were working part-time and thirtyfour $(23,3 \%)$ were housewives or worked from their home

The patients had cancer in the following sites:

Breast

40

Prostate

18

Lung

Lymphatic system

Ovary

Other

Nineteen types of cancer are combined in the other group. Because of the small number in each of these 19 categories, it was not feasible to analyse each one separately.

\section{PERCEIVED HEALTH STATUS}

Of the 146 patients that were interviewed for this study, twenty-three $(15,8 \%)$ stated that they were getting on quite well and were feeling better than they did on their last clinic visit; fifty-seven $(39,0 \%)$ indicated that they had noticed no change and were feeling more or less the same as previously; fifty-one $(34,9 \%)$ did not think they were getting on so well and fifteen $(10,3 \%)$ stated they were feeling worse. (see Figure 1)

Since it could be reasoned that responses on perceived health status may vary according to race, age, diagnosis, or sex, these variables were cross-tabulated with the four categories of perceived health status and $\mathrm{Chi}$-square tests were done.

There was no significant difference between perceived health status and race (chi-square $=7,115, \mathrm{p}=310, \mathrm{df}=6$ ), age (chi-square $=8,458, \mathrm{p}=0,74, \mathrm{df}=15$ ), sex (chi-square $=20,028, p=21, d f=16$ ) or diagnosis (chi-square $=28,029, p=0,02$, $\mathrm{df}=15$ ). Therefore it can be concluded that among this sample of patients neither race, age, sex or type of cancer were discriminating variables related to perceived health status.

Perceived health status was, however, as could be expected, found to be positively related to both symptom distress and functional status. Those patients who indicated that they were getting on well, achieved low symptom distress scores ( $\mathrm{r} 0,71 \mathrm{p}<, 0001$ ) and had few problems with activities of daily living ( $r 0,84$, $\mathrm{p}<0,0001)$.

\section{SYMPTOM DISTRESS}

As mentioned previously, the summed scores obtained on the symptom distress scale could range from 13 to 52 , with higher scores reflecting higher symptom distress. For purposes of assessment patients receiving a score of 13 were classified as experiencing minimal distress, while those receiving a score within the 1426 range were classified as experiencing moderate distress, those receiving scores within the 27-39 range as experiencing 


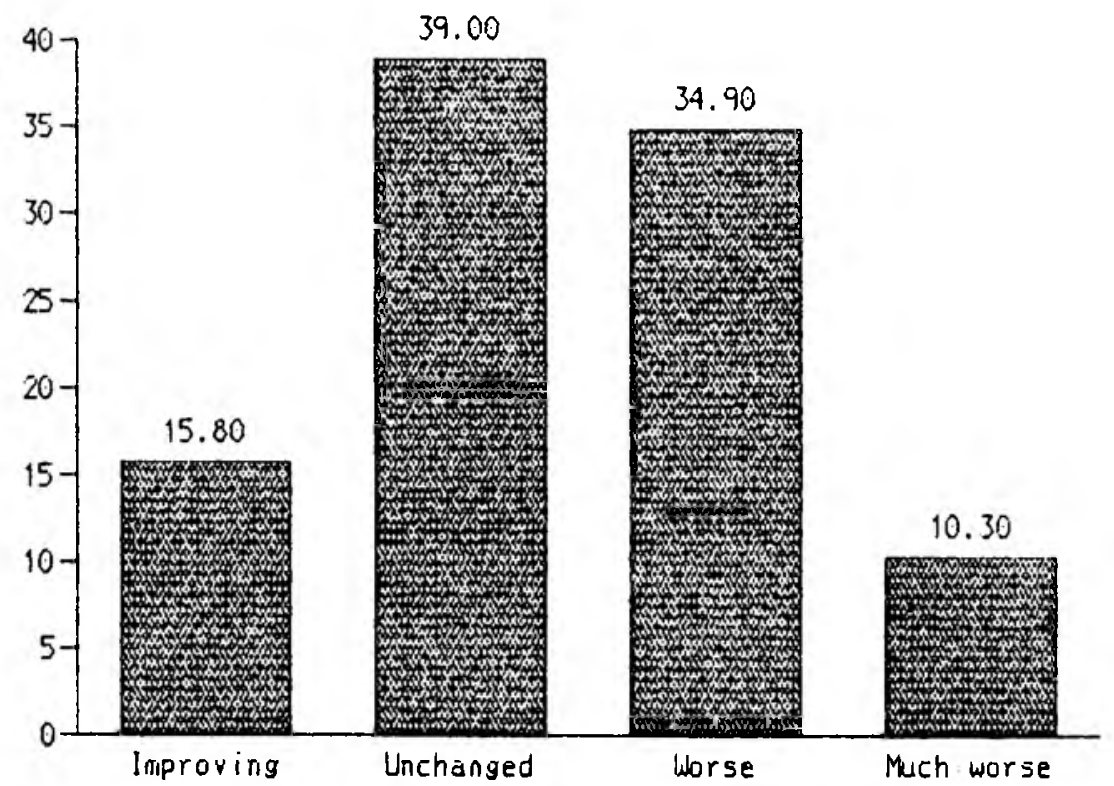

Fig. 1. Perceived health status $(n=146)$.

considerable distress and those receiving scores of 40 and over as experiencing high distress. Under this approach only one $(0,7 \%)$ patient experienced minimal distress while sixty-one $(41,8 \%)$ experienced moderate distress, seventyseven $(52,7 \%)$ considerable distress and seven $(4,8 \%)$ a high degree of distress (see Figure 2).

An analysis of the responses to each particular symptom revealed that each of the symptoms was experienced as distressing by a considerable number of respondents. However, the degree of distress experienced varied from patient to patient and also from symptom to symptom. Some symptoms appeared to be more distressing to a larger number of respondents than others. So, for example, tiredness was experienced as considerably or highly distressing by more than 60 percent of patients, while only ten percent of patients experienced diarrhoea as considerably or highly distressing. In Table

\begin{tabular}{|lcc|}
\hline \multicolumn{4}{|c|}{ TABLE 3. SYMPTOMS CAUSING MAJOR DISTRESS* } \\
Symptom & Total & Percentage \\
Tiredness & 89 & 60,9 \\
Pain & 67 & 45,8 \\
Irritability & 61 & 41,7 \\
Inability to sleep & 57 & 39,4 \\
Depression & 56 & 38,9 \\
Inability to concentrate & 55 & 38,5 \\
Loss of appetile & 52 & 35,6 \\
Loss of mobility & 50 & 34,4 \\
Appearance & 39 & 26,9 \\
Nausea & 37 & 25,4 \\
Constipation & 22 & 15,0 \\
Diarrhoea & 14 & 9,6 \\
•Receiving ratings 3 or 4 on four point scale. Corrected for \\
missing data. n for individual items ranges from $143-146$. \\
\multicolumn{3}{|c|}{} \\
\hline
\end{tabular}

3 the symptoms causing major distress to the largest number of patients are arranged in rank-order from high to low, while Figure 3 represents the percentage of persons falling within each scale dimension on each particular symptom.

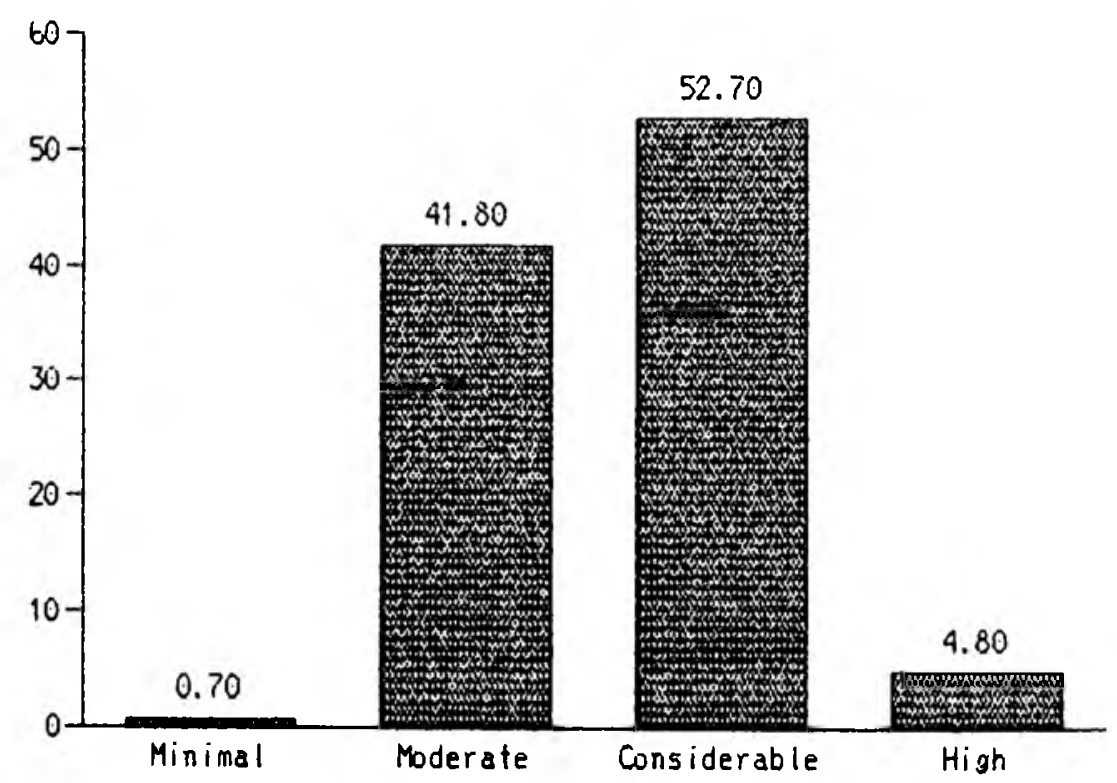

Fig. 2. Symptom distress reported by patient $(n=146)$.

Thirteen items were originally included in the instrument for assessing the functional status of patients. However, because of the very low response rate to the work activity items, these were excluded when the functional status scale was computed. A total score within a 10-63 range could be obtained on the remaining 10 items of the functional status scale. On receiving a score of 20 or lower, patients were classified as independent. They were classified as moderately dependent if they received scores within the 21-30 range and as highly dependent if they obtained scores above 30 . The scores of eighty-nine $(61 \%$ patients were low enough to be categorised as independent, while $34(23,2 \%)$ of patients were classified as moderately dependent and twenty-three $(15,8 \%)$ as highly dependent.

Travelling was the principal area of dependency with fifty-five $(37,7 \%)$ of patients requiring assistance with travel. of these nine $(6,2 \%)$ were confined to their home, and eleven $(7,5 \%)$ travelled only when really necessary.

Walking and movement ranked second in difficulty with fifty-two $(35,6 \%)$ of the patients being dependent on either special equipment or other people when walking or getting up and sitting down. Of this group eight patients $(5,5 \%)$ were unable to walk more than a few steps and nine $(6,2 \%)$ required assistance in getting in and out of bed.

Bathing was the third major area of dependency with thirty-one patients $(21,2 \%)$ requiring assistance with bathing. Seven patients $(4,8 \%)$ were completely dependent on another person for bathing, while six $(4,1 \%)$ preferred not to bath.

Twenty-four patients $(16,5 \%)$ required assistance with eating, two $(1,4 \%)$ were completely dependent on others, while a further $18(12,3 \%)$ could eat with the help of equipment if somebody else prepared the meal.

Sixteen patients $(11 \%)$ needed assistan with dressing. Three $(2,1 \%)$ could not dress at all without help from another person and four $(2,7 \%)$ spent most of the days in bedclothes.

With regard to the toileting dependency factor - only $10(6,8 \%)$ people required help when going to the toilet and one patient was incontinent.

With regard to activities in the home, only twenty-seven $(18,6 \%)$ still managed to carry out their normal household activities. Forty $(27,6 \%)$ had to modify their activities as they experienced difficulties in performing some of the routine home activities. Fifty-seven $(39,3 \%)$ had to severely restrict their normal home activities and twenty-one $(14,5 \%)$ were unable to carry out any household activities.

Of the ninety-nine patients who responded to the item pertaining to work activity $56,6 \%$ reported that they have been unable to do most of the work they previously used to do, while $22,2 \%$ were still able to carry out most of the activities they used to do before they started with treatment, but have to take it easier, and 
SCALE DIMENSIONS

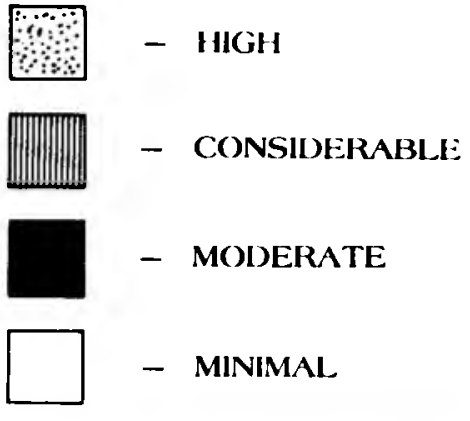

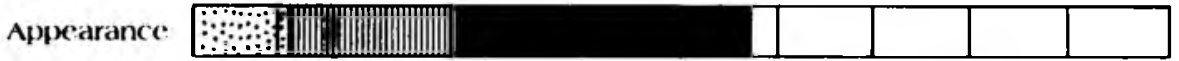

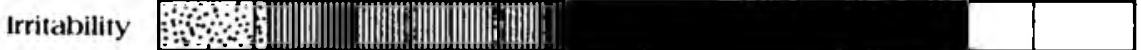

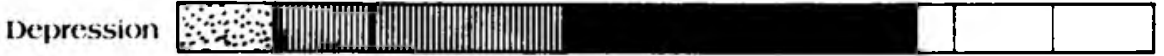
Concentration Problems $\because ;$ Finid

Tiredness

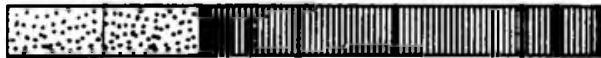

Constipation

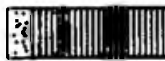

Diarrhoea

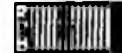

Mobility Problems

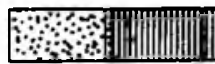

Sleep

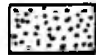

Appetite

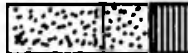

Nausea
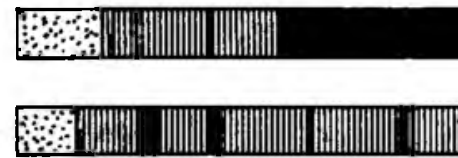

Percentage

o

10

20

30

$40 \quad .50$

6

Fig. 3. Percentage of patients experiencing distress within each scale dimension on each particular symptom.

$21,2 \%$ were able to carry out the usual activities at work that they used to do before they started with treatment.

Fifty-seven percent of the 56 patients who were still in full or part-time employment or working from their homes reported feeling much more tired after a days work than was the case before they took ill, while $28,6 \%$ felt slightly more tired and $14,3 \%$ could not really say whether they felt more tired or not. Forty-five percent of patients who were still working reported having been absent from work frequently since their last treatment, while $26 \%$ were absent occasionally and $29 \%$ were absent only when having to attend the clinic.

\section{SOCIAL ISOLATION}

Two interview items were used to assess the adequacy of the patients social interaction. The first item dealt with the frequency of participating in recreational activities that took them out the house and the second one, with the frequency of face to face contact with non-household relatives and friends. About one in five patients (19\%) still continued with their recreational activities as they had done before their illness, $26,8 \%$ participated in fewer activities and went out less, $22,5 \%$ had stopped most of their recreational activities and $31,7 \%$ did not participate in any recreation. As for the face to face contact with non-household friends, almost one in three $(31,3 \%)$ still had contact at least once a week, $27,8 \%$ still saw their friends at leat three times a month, $26,4 \%$ less than once a month and $14,6 \%$ hardly ever had contact with people other than their immediate household relatives.

The respondents' level of social interaction was assessed on the basis of their engaging in extra-household interaction at least once a week and participating in at least one recreational activity on a regular basis. Respondents meeting both these criteria $(31,3 \%)$ were classified as having minimal interaction problems. Those meeting only one of the criteria $(42,3 \%)$ were classified as moderately isolated and those failing to meet either of these criteria $(26,9 \%)$ as highly isolated.

\section{COMMUNICATION ABILITY}

Communication ability was assessed by the interviewers on the basis of the nature of responses obtained during the interview. Of the 140 patients who were assessed on this, $59,5 \%$ of patients responded in a normal coherent manner to the questions asked; $20 \%$ responded to the questions but added much irrelevant information, while $20,7 \%$ of patients did not respond directly to the interviewer and required much prompting to elicit answers.

The correlations matrix yielded several interrelated areas of concern, among them being those between pain, loss of appetite, tiredness, constipation and instrumental activities in the home and those between mobility problems, tiredness, appearance and the activities of daily living; between appearance and social and recreational activities, and between concentration, depression, irritability and communication.

Factor analysis confirmed five factors: activities of daily living, social well-being, mental well-being, overall general wellbeing and instrumental activities, thereby giving credibility to the validity of the instrument used for interviewing. Furthermore, those patients achieving a low symptom score also achieved low scores on the second section ( $0,74 \mathrm{p}<$ $, 0001)$ thus confirming the assumption that symptom distress has a significant impact on the activities of daily living.

\section{PROBLEMS AND CONCERNS}

The last question in the interview schedule was an open question, namely "Are you having any other problems or concerns that trouble you?" Of the 146 patients in the sample $39 \%$ did not respond to this question. Unfortunately the reason for the non-response is unknown. It may be that the interviewers omitted the last question, or that patients were reluctant to talk about their concerns. In a study done in 1986 on changing communication patterns of cancer patients, Abrams had observed that patients with advanced cancer give evidence of being reluctant to talk about sensitive topics. It may also be that patients had no further concern. Twentytwo patients $(15,1 \%)$ spontaneously 
answered no, they had no further concerns and the remaining sixty-seven $(45,9 \%)$ voiced one or two concerns. Finance was a dominant problem voiced by sixteen patients $(11 \%)$. Thirteen $(8,9 \%)$ indicated that they were worrying about the uncertainty of their future or that of their young children; eleven $(7,5 \%)$ were unhappy about the long time they had to spend waiting at the clinics, yet not being given enough time to ask questions, and an equal number were worried about deteriorating interpersonal relationships and their symptom distress. Other problems were transport, inability to accept their condition, fear of

chemotherapy treatment, deteriorating marital relations, problems with employers who won't believe they have to attend the clinic so often, The impersonal atmosphere at the clinic, insufficient recreational activities for lonely patients and doctors who were not encouraging.

\section{DISCUSSION}

Clearly the findings derived from a smallscale single cross-sectional survey cannot be regarded conclusive of the functional status of all patients with advanced cancer in the country. This fundamental methodological constraint is further aggravated by limitations associated with sample size, response rates, investigators and by the element of judgement inherent in any evaluation effort. Nevertheless, both the primary and secondary purpose of the study was met. From the completed interview schedule it was possible to identify common areas of particular concern to patients with advanced cancer as well as existing needs and areas of particular concern of individual patients. The profile constructed from the data revealed that the patients with advanced cancer in this country do not differ substantially from those in the USA and the UK. Previous findings by McCorkle (1976) that self-care social and mobility problems were major concerns of patients with advanced cancer were confirmed. The positive interrelationships between

symptom distress and the activities of daily living found in this study is consistent with the findings of McCorkle and Young (1980) and Holmes and Dickerson (1987).

The demonstrated relationships between particular symptoms and activities such as, for example, pain, loss of appetite, tiredness, constipation and instrumental activities, were not unexpected and can be satisfactorily explained.

The finding of no significant difference in functional dependence according to age was somewhat unexpected as aging is generally associated with increasing dependence. The relatively small sample may of course have produced unstable results in this regard. This matter thus requires further attention. On the other hand nurses should also be made aware that they should bear this finding in mind in their intervention with patients.

Both sections of the research instrument were shown to be reliable by computation of Cronbach's coefficient alpha. The results of individual items also appear to be reliable. The instrument, furthermore, appears to be a valid means of assessing patient well-being and functional status, and could be used by nurses to assess the symptom distress and functional status of patients with advanced cancer. Use of a standardised instrument would ensure that patients are assessed more systematically and comprehensively and not merely from individual established criteria. It would also help nurses to assess changes in their patients so that they can adjust their nursing care plans and approaches. For example, a change in either symptom distress or functional status could provide the cue for teaching the patients methods of approaching a particular activity. It may also signal the need for care plans to be adjusted, or to coordinate the care with other relevant health-care services. The instrument could also be useful in helping nurses to evaluate the outcomes of their nursing care approaches and their counselling and could be a valuable supplement to clinical practice.

The length of time required for an interview by means of this instrument may act as a deterrent to its use. However the actual time was longer than expected and with practice could be reduced to about ten minutes. The need for patients to talk about their anxieties and concerns and to ask questions was identified in the study. Even though only a small number $(7,5 \%)$ actually verbalised the need, this does not mean that the need does not exist. It thus seems vital that nurses should devote time not only to talking to the patients but also to listening to the patients and making it clear that they do in fact recognise and understand individual difficulties.

Interviewing patients by means of this instrument would provide an opportunity for such sessions. This surely forms an important part of total patient care.

Besides the need for a listening ear, several other needs requiring attention were identified in this study. For example, a small group of patients complained of the long waiting time. Even though this is probably inevitable, the resourceful nurse could plan or organise activities to make the time go faster. The lonely patient in need of recreational facilities could be introduced to such facilities or arrangement could be made for her to join a club catering for functionally dependent people.

With symptom distress limiting the daily activities of more than one out of three patients and being a major cause of work and home activity dependence in one out of two, and also playing an important role in the social isolation observed in two out of three patients, more attention needs to be given to alleviating such symptoms. Nurses also need to ask themselves to what extent they are attempting to meet the emotional needs of their patients.

Because of several limitations mentioned earlier, it is recommended that the study be repeated on several more samples of patients with advanced cancer, and that the method of triangulation be used, that is that a variety of methods are used to collect data in the same way, to see whether similar results are obtained.

It is also recommended that the study include several more aspects, such as, for example, finding out what resources are available to patients, such as, for example, self-care help, home assistance, financial assistance, transport and so on, and whether patients are aware of all the services available in their community. It may also be useful to include a question on the length of time the person has been on treatment and the date of their first diagnosis. Comparisons could be made between symptom distress reported by patients and objective assessment of the same patients made by nurses. A study could also be made of the nurses' knowledge of services available to these patients and their knowledge of problems faced by patients.

\section{REFERENCES}

1. Abrams R. 1986. The patient with cancer his changing pattern of communication. New England Journal of Medicine, 17.4. p. 319-322.

2. Benoliel J.Q., McCorkle R.M., Young K. 1980. Development of a social dependency scale. Research in Nursing and Healih, 3: 3-10.

3. Holmes S., Dickerson J. 1987. The quality of life: design and evaluation of a selfassessment instrument for use with cancer patients. International Journal of Nursing Studies, 24: 1: 15-24.

4. McCorkle R., Young K. 1978. Development of a symptom distress scale. Cancer Nursing. 1: 373-383.

S. McCorkle R., Benoliel J.Q. 198 I. Cancer patient responses to psychosocial variables. Unpublished report. University of Washington.

6. Young K., Logman A.J. I983, Quality of life and patients with melanoma: $A$ pilot study. Cancer Nursing, 7: 219-225.

Special acknowledgement

In conclusion I wish ro acknowledge

1. the contribution of the four Chairmen of the Regional Oncology Nursing Societies. Mrs $M$. Bezwoda. Miss W. Grobbelaar, Mrs J. Lancaster and Mrs $T$. Stas and their assistants to the project. Without them the investigation would not have materialised.

2. The Universily of Soush Africa, for a research grant which made this study possible.

H.I.L. Brink, D. Litt et Phil (S.A.) R.N., R.M., R.T., R.N.A., R.C.H.N Professor, Dept of Nursing Science University of South Africa 